\title{
Influence of Modern Scientific and Technological Revolution on the Current Art Education in Colleges
}

\author{
LiJing Chen \\ Weifang College, Weifang, Shandong, 261061
}

\begin{abstract}
Modern scientific and technological revolution plays an important role in the development process of the society. But it is generally known that technical revolution is natural science, but art education is social science. And the direct and indirect connection of both is the emphasis in the paper. From the perspective of philosophy, the paper dialectically expounds the relationship between modern scientific and technological revolution and art education. Especially the art education in colleges is expounded as an example in the paper. Both of them not only have contradictions and mutually promote, but also has the relationship of mutual restriction. However, science and technology dominates in the development process of the society, and the development direction must influence the development direction and trend of art. And the it has significant influence on the education with the most art talents. How to correctly comprehend the restriction relationship between them not only has great significance to guide the present art education in colleges, but also can properly aster and guide the development direction and trend of art education in colleges.
\end{abstract}

Key words: modern scientific and technological revolution, ornamental art education, practical art education, art in colleges

\section{INTRODUCTION}

Art education in colleges is the branch of the whole art education. As the art in visual field, it burdens the task of the society cultivating the development variation has close relationship with the social development, in which the development science plays a decisive role in the development of human society. Therefore, scientific development is a dominant factor for the development of art education, but all the leading factors may be not favorable factors. It includes the factors restricting the development of art education. So how to properly comprehend the influence of science and technology on art and how to properly analyze the pros and cons of the relationship is necessary and urgent for the art education in colleges. Therefore, properly comprehending the relationship between them not only can reduce the influence of adverse factors on art education in colleges, enhance the promotion of favorable factors, promote the art education in colleges to keep with the times, and make the art education in colleges serve the society, but also can solve the problem that adaptive art talents are deficient with the advance of science and technology.

\section{Concept of Modern Scientific and Technical Revolution and Art Education in Colleges}

2.1 Concept of modern scientific and technical revolution

Modern scientific and technical revolution begins from the revolution of physics in the early $20^{\text {th }}$ century, and is marked by the development and application of nuclear engineering technology, electronic computer technology and space technology in the middle of the $20^{\text {th }}$ century. And it is a new scientific revolution with the feature that natural science, social science and 
cognitive science are inter-infiltrated to form inter-discipline. [1] Modern scientific and technical revolution not only includes astronomy, geology, biology, chemistry and physics, but also includes social science and consciousness science filed. Modern science system is the social phenomenon and special social manner with wide relation and influence. And it is the dynamic knowledge system which can properly reflect the essence and rule of nature, society and spirit phenomenon of the mankind.

\section{2Concept of art education in colleges}

Art is a social ideology, and belongs to the art category of visual field. The range of art is wide. It can be divided into ornamental art and practical art [2]. Ornamental art includes painting and sculpture, and the art form is generally the continuous development of traditional art. Practical art includes industrial art and building, and the art form is creative art.

The current art education in colleges is generally divided into art education of professional art colleges and art education of comprehensive colleges. The art education of professional art colleges are more inclined to artistry, and focuses on the cultivation of ideology. The art education of comprehensive colleges are more inclined to practicability, and emphasizes the cultivation of comprehensive ability, which has close relationship with the educational mission of the colleges. Generally speaking, the art education in colleges is classified based on the types of art, and the setting and classification of majors is based on the classification of art. It is common that there are two main majors, artistry and art design. Artistry belongs to ornamental art category of art. It covers pure painting art and basic art education, in which pure painting art includes Chinese painting, oil painting, print, sculpture and traditional painting. The setting of courses is unitary and has great pertinence. And basic art education focuses on the cultivation of comprehensive art accomplishment and theory. Art design belongs to the practical art category of art. The setting of the includes majors has close relationship with the times and social life influence. It includes environmental art design, visual communication art design, costume art design, porcelain art design and cartoon art design, and it includes all visual art forms relating to the society and life.

The content and the branch of the current art education in colleges is detailed and complicated, but it doesn't break away from the branches of art, ornamental art and practical art, the reason for which is the features and the characteristics of the art forms. Ornamental art emphasizes the accomplishment and inheritance of art. It is influenced by the society, but the influence is not evident compared with practical art. Practical art has close relationship with the social development, and the influence of scientific and technical development is more evident. Therefore, properly comprehending the influence of modern scientific and technological revolution on the present art education in colleges must analyze two fileds of art education.

\section{Influence of Modern Scientific and Technical Revolution on Ornamental Art Education in Colleges}

It has been expounded that the ornamental art education of the present art education in colleges mainly covers pure painting art and basic art education. The modern scientific and technological revolution has developed from the $19^{\text {th }}$ century. And the influence on ornamental art education in colleges is manifested on manor setting, enrollment number, configuration of teachers and teaching form. The paper takes Weifang Colleges [3] as an example, and uses the chart to show the influence of the development of modern scientific and technical revolution on ornamental art education in colleges. 
Table: 1 Ornamental art education in colleges

\begin{tabular}{|c|c|c|c|c|c|}
\hline & Year & Major setup & $\begin{array}{l}\text { Enrollment } \\
\text { number }\end{array}$ & $\begin{array}{l}\text { Configuratio } \\
n \text { of teachers }\end{array}$ & Teaching form \\
\hline \multirow{4}{*}{$\begin{array}{l}\text { Ornamental art } \\
\text { education in } \\
\text { colleges } \\
\text { ( Art school } \\
\text { in Weifang } \\
\text { college) }\end{array}$} & 1980-1989 & 1 & 20 & 5 & traditional \\
\hline & 1990-1999 & 3 & 90 & 10 & traditional \\
\hline & 2000-2009 & 4 & 90 & 20 & $\begin{array}{l}\text { Traditional teaching } \\
\text { form is combined } \\
\text { with multimedia }\end{array}$ \\
\hline & $2010-$ & 4 & 100 & 25 & $\begin{array}{l}\text { Traditional teaching } \\
\text { form is combined } \\
\text { with multimedia }\end{array}$ \\
\hline
\end{tabular}

(The chart indicates that the year group is classified with ten years as a stage. The art academy in Weifang College was established in 1978, and enrolled the students in 1980. There was only a major from 1980 to 1990, art education major, and the college only allocated 5 professional teachers. In 1994, art education major was divided into Chinese painting, oil painting and basic education. After art academy was named in 2005 , printing major was added, and there is no change until now. In recent years, the increase of employment pressure makes that pure visual art can't meet the social requirements of rapid development any more. The college strives to solve the employment of the students of the major, but there are fewer and fewer students choosing the major, and the teachers are saturated.)

From the chart, we can see that there is necessary correlation between modern scientific and technical revolution and ornamental art education in colleges, which is inseparable from the influence of modern scientific and technical revolution on the social progress. Objectively, the influence is not evident. For major setup, with the development and progress of modern scientific and technical revolution, the influence is evident in the initial stage. With the development of advanced science and technology, the influence on the art circle increases, which must influence the development of ornamental art education in colleges. However, with the increasing maturity of the society, the influencing level evidently reduces. The major setup has no change from 2000 to now, which indicates that the ornamental art education has tended to be mature. For enrollment number and configuration of teachers, with the development of modern scientific and technical revolution, the number increased before 2000 , which indicates that the number of the people who are willing to be engaged in ornamental art increases. After 2000, the number increased, but it is evident that the requirement of the society for ornamental art reduced. For teaching form, the modern science and technology is advanced, but traditional teaching form still is predominant in ornamental art education, which is decided by the features of the major. Form the above analysis, we can see that the development of modern technology and science must influence the development, and it may play adverse role. We cannot deny the promotion function of modern scientific and technical revolution for ornamental art education in colleges. However, we must objectively admit that modern scientific and technical revolution restricts the development of ornamental art education. For example, as an important branch of ornamental art education, the real traditional value of the folk art education has lost the historical 
value in the the process of modern scientific and technical development. The present related education only remains inheritance based on protection, the reason for which is that the scientific and technical progress caused by modern scientific and technical revolution. Traditional art form can't adapt to the social development caused by scientific and technical development, which finally makes it disappear from the historical stage.

Table 2. Ornamental art education in colleges

\begin{tabular}{|c|c|c|c|c|c|}
\hline & & Major setup & $\begin{array}{c}\text { Enrollment } \\
\text { number }\end{array}$ & $\begin{array}{l}\text { Configuratio } \\
\text { n of teachers }\end{array}$ & Teaching form \\
\hline \multirow{4}{*}{$\begin{array}{l}\text { Ornamental art } \\
\text { education in } \\
\text { colleges } \\
\text { (Art school in } \\
\text { Weifang college }\end{array}$} & 1980-1989 & 0 & 0 & 0 & - \\
\hline & 1990-1999 & 2 & 40 & 8 & traditional \\
\hline & 2000-2009 & 4 & 60 & 26 & $\begin{array}{c}\text { Traditional teaching form } \\
\text { is combined with } \\
\text { multimedia }\end{array}$ \\
\hline & $2010^{-}$ & 6 & 200 & 34 & Multimedia, network \\
\hline
\end{tabular}

(The chart indicates that the college added practical art major in 1992, and divided into practical art major into environmental art design and decorative art design major in 1994. It was renamed as Art College in 2005, and the art design department was set up, which included indoor design, ceramics design, visual communication and costume design. From 2010 to now, the college is adding two majors, cartoon design and web design. The new majors not only are combined with the times and the society, but also fully show the influence of modern scientific and technical revolution on art education major setup. While adding majors, the art college introduces senior teachers of art design, and expands the enrollment number, and improves the teaching technology and level.)

From the above chart, we can see that the art college had no practical art education before the 1990s, which means that the birth of practical art education has close relationship with the advance of modern

\section{Influence of Modern Scientific and Technical Revolution on Practical Art Education in Colleges}

After analyzing the influence of modern scientific and technical revolution on ornamental art education in colleges, the paper still takes the art academy in Weifang College as an example to make comparative analysis on the major setup, enrollment number, configuration of teachers and teaching form of practical art education in colleges with the form of the chart. We can see that the results are different from the results in the above chapter. 
example, new web design major is the necessary product of the scientific and technological progress.

\section{Relationship Between Modern Scientific and Technical Revolution and Art Education in Colleges}

From the above analysis, we can see that modern scientific and technical revolution not only has multi-aspect and multi-angle influence on art education in colleges. It not only restricts ornamental art education, but also promotes practical art education. How to properly comprehend the functional relationship of scientific and technical revolution on art is necessary and urgent for the development tendency and direction of art education in colleges.

\section{Restrictive function}

The essence of ornamental art education is subjective performance on objective thighs by visual feeling, accomplishment and artistic ability. Therefore, for the people who are engaged in ornamental art, the accomplishment of artistic ability is the most important, which needs time. However, with the development and progress of science and technology, the brain and hands of the people are replaced by computers and machines. Therefore, ornamental art education only remains the level to be appreciated. When the students create art works today, no matter conception or draft depends on computers. The value of most students using hands and brain to create value is greater than the value created by scientific and technical products. There are fewer and fewer students learning the major. With the reduction of enrollment number, in order to solve the problem of teacher-capital balance, most colleges require the teachers of ornamental art education to incline on practical art education. Therefore, with the development of modern science and technology revolution and the impact of new ideology, for the influence on ornamental art education, the advantages are more than the disadvantages, which means that modern scientific and technical revolution restricts the development of art education form.

\section{Promotion function}

Compared with ornamental art education, practical art education has different circumstances. With the development of modern science and technology, the society is advancing. New science and technology promotes new requirements, and the birth of more and more industrial products promotes the development of practical art education. Some objective substances in daily life needs to be assigned the meaning of beauty. Any advanced scientific and technical products needs the package of beauty. Therefore, practical art education is the major which has close relationship with modern scientific and technical revolution.The art forms relating to daily life of people such as furniture design and industrial design, and the art forms of computer design and web design manifest the promotion function of modern technical revolution for practical art education. All things relating to the mankind require the decoration of art. Obviously, it is the product of the development and progress of modern scientific and technical revolution. Therefore, the birth of practical art education and the expansion in the future has close relationship with the modern scientific and technical revolution. Modern scientific and technical revolution not only promotes the development of practical art education, but also guides the development direction of practical art education.

3. Properly processing the relationship of restriction and promotion

Art is a social consciousness form. Modern scientific and technical revolution is a comprehensive all-around revolution including the revolution of social consciousness form. Therefore, as the important form of transmitting art concept, art education in colleges, has close relationship with the progress of scientific and technical revolution. We cannot only realize the restriction of modern scientific and technical revolution on ornamental art education and deny the disadvantages of scientific and technical development, and cannot only emphasize the promotion function on 
practical art education. It is obvious that we should properly analyze and regard the problem from the perspective of philosophy. We cannot deny the progress of modern science and technology, and cannot prevent from the birth of modern scientific and technical revolution achievements. We should reduce the influence on ornamental art education, and we can't consider that new high-tech products and idea must be right.

\section{Conclusion}

We should dialectically regard modern scientific and technical revolution, which can make art education in colleges adapt to social development and modern scientific and technical revolution development. And the art education in colleges can develop properly and smoothly.

\section{Acknowledgement:}

This thesis "research topic for social science of Weifang University", "Weifang University doctoral research fund project" results.

\section{Reference:}

[1] Huang Shunji, Guo Guichun, Modern scientific and technical revolution and Marxism (Common required course for Doctor in Colleges in China)[M],China Renmin University Press, 2007: the first part.

[2] Deng Fuxing, Introdction of art [M], Shanghai Renmin Art Press, 2009.1:the first chapter.

[3] Yin Jianmin, Inheritance and development-history of Weifang College, Shandong Press, 2011.10:341 366.

[4] Chen Shijun, Modern scientific and technical revolution and Marxism, Tianjin University Speech, 2011.12: the fourth subject.

[5] Zhang Qinyuan, Modern scientific and technical revolution and human civilization, Speech of East China Normal University, 2004:8.

[6] Wang Yuding, Thinking on higher education development under the background of modern scientific and technical revolution [J], Journal of Hebei Agricultural University, 2009.9 (3) : 1 4.

[7] Liu Ying,Analysis on modern scientific and technical revolution and cultivation of innovation-type talents in colleges in China [J], Higher Education, 2011.9.

[8] Ma Yuejin, Chen Zhiqiang, Yu Fengkun, Modern scientific and technical revolution and cultivation of talents in colleges [J], Journal of Huazhong Agricultural University, 2005 (10) : 141-144.

[9] Shen Jiahua, Analysis of establishing art appreciation in colleges [J], Journal of Guangxi Education College, 2000.3.

[[10] Ma Guojun, Observation on national art quality education of university [J], Journal of Gansu Education College (Social Science), 2004.1. 